\title{
Using Cooperative Teams-Game-Tournament in 11 Religious School to Improve Mathematics Understanding and Communication
}

\author{
${ }^{1}$ Arsaythamby Veloo, ${ }^{2}$ Ruzlan Md-Ali, \& ${ }^{3}$ Sitie Chairany \\ ${ }^{1 \& 2}$ School of Education and Modern Languages, \\ Universiti Utara Malaysia, Malaysia \\ ${ }^{3}$ Madrasah Aliyah, Riau, Indonesia
}

\begin{abstract}
Purpose - This paper was part of a larger study which looked into the effect of implementing Cooperative Teams-Games-Tournament (TGT) on understanding of and communication in mathematics. The study had identified the main and interaction effect of using Cooperative TGT for learning mathematics in religious secondary school classrooms. A recommendation was made to incorporate Cooperative TGT as a pedagogical approach to enhance interest in actively learning mathematics with peers via tournaments among students. Students in Cooperative TGT classrooms had also learned to socialise while learning mathematics.
\end{abstract}

Methodology - A quantitative approach using Randomized PretestPosttest Control Group design was utilised in framing the research study. Simple random sampling was used to select 64 Grade 11 students from Madrasah Aliyah, Riau, Indonesia. Data from control groups without TGT treatment was collected using pretest, posttestland posttest- 2 across three time periods. The duration between one test and the subsequent test was five weeks. Mathematics understanding and communication was measured using an openended test. A mixed between-within subjects ANOVA was conducted to analyse the effectiveness of Cooperative TGT on understanding of and communication in mathematics.

Findings - The findings showed that there was significant interaction between group types (experiemental \& control groups) and time periods [pretest, posttest- $1, \&$ posttest- 2 (without TGT)]. Cooperative 
TGT was found to have an effect on student understanding of and communication in mathematics. The gap score for posttest- 1 between understanding of mathematics and communication in mathematics was 17.69, indicating a significant effect of Cooperative TGT on the latter compared to the former.

Significance - Cooperatiave TGT had encouraged students and teachers to be innovative and creative in the process of teaching and learning of mathematics in classrooms. This study has provided insights into how the teaching and learning of mathematics which incorporated group activities and tournaments in classrooms has helped to improve the understanding of mathematics and communication in mathematics of students at the Madrasah Aliyah, Riau, Indonesia.

Keywords: Understanding of mathematics, Communication in mathematics, Cooperative Team-Games-Tournament; Interaction effect

\section{INTRODUCTION}

The reason for conducting a study of teaching is to better understand and ultimately improve student learning. One must examine what actually happens in the classroom, studying the teaching intentionally designed to facilitate students learning. Relationships between classroom teaching and learning are complicated, nevertheless it is well documented that teaching makes a difference in student learning (National Research Council, 1999). If the quality of mathematics teachers' instructions meets the expectations of their students, the latter would probably be more engaged during mathematics instruction. However, more competent students can be more critical and demand a much more challenging classroom environment with interesting things to do during mathematics lessons. Less competent students, on the other hand, may not be perturbed by the classroom learning and teaching environment. High achievers may not be deeply engaged during classroom instruction when the quality of instruction does not meet their expectations (Rosna, Arsaythamby, \& Ruzlan, 2014). 
According to Johnson and Johnson (1991), success and group dynamics were very important in student learning. A study by Tsay and Brady (2010) found that there was a positive relationship between cooperative learning and academic performance, and in the higher education context this was in terms of student ability to communicate. The finding supports the fact that cooperative learning can be a good teaching and learning method to achieve high academic performance. Research pertaining to the use of cooperative learning in teaching and learning had been carried out in various countries. For instance, Kamuran and Fikri (2008) had carried out a study on the effects of cooperative learning on Turkish elementary students using TAI and STAD methods. The subjects in their study were 248 fourth-grade students in Adana, Turkey. They reported that the cooperative learning methods STAD and TAI were more effective in terms of academic achievement than the traditional methods. Ke and Grabowski (2007) had carried out a study that looked into the effects of game playing on the mathematics performance of fifth-grade public-school students in central Pennsylvania. These participants were recruited and assigned to a cooperative Teams-Games-Tournament (TGT). The result of their study indicated that mathematics game playing did promote test-based cognitive learning achievement and the game playing context (cooperative or interpersonal competitive TGT) played a significant role in moderating the effect of educational gaming on affective learning outcome.

The Mathematics subject is compulsory in all public and religious schools in Indonesia. Despite using the same Mathematics curriculum, the teaching and learning of mathematics in these two types of schools are different (Supriyono, 2011). The focus in religious schools is more on Islamic Education and the students feel rather anxious to follow the general subjects, especially Mathematics. Supriyono (2011) also pointed out that Religious Schools Education in Indonesia pay little attention to general subjects, especially Mathematics. Consequently, student achievement in mathematics is lower than their achievement in religious subjects. Students at religious schools do not actively participate in classroom mathematics learning because they feel that the teaching and learning process is not interesting (Muhammad, 2009). Even though Mathematics is a compulsory subject, it is the second choice for Indonesian students when it comes to furthering their education. 
The role of school mathematics curriculum is to deliver mathematics concepts and ideas in the verbal, written, graph and figure form (Ulya, 2007). It is important for students to be competent in their mathematics learning process because their level of thinking is still low and is procedural in nature (Mullis et al., 2012). Generally, the learning of mathematics involves the learning of problems given by teachers and one of the intended aims to be achieved in learning mathematics is to give students the broadest possibilities to integrate mathematics knowledge, skills and practice. In enhancing the students understanding of mathematics, their competence in mathematics communication also need to be enhanced (van EsElizabeth \& Conroy, 2009). As pointed out by Huinker and Laughlin (1996), verbal and written communication could bring about deeper understanding of mathematics among students and also contribute towards their mathematics achievement. Furthermore, a student-centred approach would encourage students to actively participate in mathematics learning activities (Melvin \& Silberman, 2006).

One teaching approach that involves group work in classroom is known as cooperative learning. Cooperative TGT is a kind of cooperative learning which involves cooperation among students in small groups, whereby students are encouraged to help each other to accomplish a given task. The process of cooperative TGT teaching and learning, which was developed by Slavin (1995), is a learning approach that combines learning group and team tournament and can be used to enhance understanding of concepts and communication. In cooperative TGT, students play academic games with other team members to collect points that will contribute towards group score. Members within a particular group would help other team members to accomplish the tournament task, for example, completing the task worksheet and would ensure that every member had understood the task. During the tournament, each team member would be playing according to their own abilities without the help of other team members.

\section{PROBLEM STATEMENT}

The National Research Council had reported that from a global perspective, student mathematics achievement in the United States was low and their competence in mathematics understanding 
was limited (van Es Elizabeth \& Conroy (2009). Mathematics understanding and communication has indeed become a gobal concern. It is noteworthy that the issue related to Mathematics understanding among students in Indonesia and other countries in the region is also a growing concern (Rosna, Arsay, \& Ruzlan, 2014). According to Patricia (2011), student success in mathematics learning was constrained by a limited understanding of mathematics concepts. Students who were not able to acquire mathematics concepts viewed mathematics subject as very difficult. The students were more inclined to memorize, they were less creative and found it difficult to expand their cognitive abilities. All these issues contributed to their low engagement in mathematics learning, mathematics achievement, and their ability to understand mathematics as well as their mathematics communication (Keri \& Plattsmouth, 2010). The conventional approach obviously did not promote much interaction and students appear to be passive learners (Duatepe-Paksu\&Ubuz, 2009). The limited interaction and discussion sessions made the learning process appear boring or mundane. There was no opportunity to discuss or actively explore concepts that students did not understand. They might not be able to understand the teaching materials and retain pertinent mathematical concepts and hence, found the lessons boring and uninteresting (Honeycutt \& Pierce, 2007). Similar situations are happening in religious schools in Indonesia. For instance, according to Ulya (2007), the teaching and learning process in Aliyah Religious School focused less on the students' ability to understand mathematics as well as their mathematics communication. Many teachers have begun to use cooperative TGT learning because the activities were appealing to students (Slavin, 1995). There had been studies pertaining to outcomes on the use of TGT in education, but only limited studies in its use in the teaching and learning of mathematics (see for examples, Arnold, 2008; Horton, Storm, \& Leonard, 2004; Choo-Kim, Madhubala, \&Siong-Hoe, 2011). However, studies regarding the use of cooperative TGT in Indonesia's religious schools mathematics classrooms are scarce.

\section{Mathematics Understanding based on Cooperative Learning}

Graceful and Raheem (2011) explored the effect of Think-PairShare (TPS) and Reciprocal Teaching (RT) cooperative learning approaches on student performance in mathematics understanding. 
Their research findings indicated that the RT cooperative learning approach was more effective for mathematics understanding, followed by the TPS cooperative learning approach. The conventional approach was found to be the least effective among the three approaches. Charalampos (2004) had carried out a research on cooperative teams in the mathematics classroom. The research findings showed that student involvement in the cooperative team activities had not only supported the enhancement of student mathematics understanding, but had also motivated them to identify the importance of mathematics concepts, attitude, attendance, and task accomplishment in classrooms.

Linda (2004) had studied the effect of the cooperative jigsaw approach towards mathematics learning. This study also discussed mathematics understanding that used the cooperative jigsaw and conventional learning approaches. The results of the study indicated that mathematics understanding in the jigsaw approach was higher than that in the convensional learning approach. The study also reported that students in the cooperative jigsaw group performend better than those in the convensional learning approach group. Based on their research findngs, Tanner and Marr (1997), Slavin (1997) and Whickerat al. (1997) claimed that when exposed to cooperative learning approaches, students were found to become positive through the processes of inculcating ideas, problem solvings and group interactions. Student understanding of mathematics concepts were better when sharing tasks. They learned to use their thinking when solving complex mathematical tasks and indicated a tendency to provide logical explanation.

Though all the studies discussed above had pointed out a significant increase in student ability to understand mathematics through cooperative learning approaches, there were also studies that showed just the opposite findings. For instance, in a study carried out by Ansari (2004), which considered the enhancement of mathematics understanding and mathematics communication among secondary school students using the Think-Talk-Write (TTW) cooperative learning approach for small group, it was reported that the student scores for understanding and communication after using the TTW approach did not reach the average score. Hence, indicating that the TTW approach was not effective for the group of students in the study. 
According to Ansari, there were some elements that constituted the reasons for the ineffectiveness of the TTW approach, which included the lack of prerequisite knowledge, the learning process that all the while was teacher-centred, the low ability to read and discuss, and the large class size. Furthermore, Ansari (2004) reported that the inculcation of the TTW approach had an especially low effect on students with weak prerequite skills. Amy and Omaha (2011) had carried out a research on the effectiveness of cooperative groups on written and oral communication among Grade 8 American students. This research had used student daily cooperative groups. The research findings showed that through the daily interaction between students there was an increase in written as well as oral communiation, and students had comfortably worked together within their groups. In a research carried out by Tsay and Brady (2010), a positive relationship was found between cooperative learning and mathematics achievement, more specifically with regard to enhancing student communication ability. This finding supports the idea that cooperative learning is an active pedagogy which facilitates higher academic achievement. The research findings also showed that group evaluation and success were more important for the students compared to peer acceptance and the feeling of achievement, though the literature indicated a strong relationship with group achievement.

It has been reported in some studies that cooperative learning could result in enhancement and active learning of mathematics in classrooms. For instance, Keri and Plattsmouth (2010) had researched on mathematics communication within cooperative learning groups among Grade 7 American students. Their research findings showed that cooperative learning groups enhanced mathematics communication, for example, the use of vocabulary, oral discussions, and written explanations. This approach also assisted students in enhancing their understanding of mathematics concepts. Galton, Hargreaves and Pell (2009) had carried out a research on cooperative learning and mathematics communication and their findings showed that cooperative learning had increased student mathematics communication through cooperation, discussions and the ability to work freely without feeling anxious towards other students.Wiebe-Berry and Kim (2008) had researched on the effect of cooperative learning, communication and the 
understanding of mathematical concepts. The research findings showed that communication and cooperative learning had increased student understanding of mathematical concepts. Wiebe-Berry and Kim (2008) pointed out the importance of communication for the development of understanding and the process of mathematics discovery among the students in cooperative learning.

In other approaches of cooperative learning used in mathematics classrooms, researchers had reported similar gains in mathematics learning, in particular its contribution towards positive interaction and communication. Isrok's (2006) research indicated that mathematics communication in Student Teams-Achievement Divisions (STAD) cooperative learning exceeded that of conventional learning. The study also showed that there existed a relationship between student ability to solve mathematics problems and their mathematics communication. Students with high problem solving ability showed a high ability in mathematics communications, and vice versa. Wihatma (2004) had carried out a study in a secondary school that looked into the effect of STAD cooperative learning in increasing the mathematics communication ability of students. The research showed that student mathematics communication ability had increased.

As for cooperative TGT learning, Ulya (2007) found that it affected mathematics communication. The study reported that the use of cooperative TGT learning had resulted in an increase of the mean score of mathematics communication compared to the use of conventional learning. The study also found a significant difference between the cooperative TGT learning posttest and the conventional learning posttest. The highest increase was in the skills relevant to mathematics communication.

\section{The Underpinnning Theories}

Mathematics involves an extensive hierarchy of concepts and any one particular concept cannot be formed until all the subsidiary ones upon which it depended has been formed (Skemp, 1986). He argued that learners would construct schemata to link what they had already known with new learning. Skemp also suggested that there were two types of learning in mathematics, namely 
learning for instrumental understanding and learning for relational understanding. Instrumental understanding refered to a mechanical, rote or 'learn the rule/method/algorithm' kind of learning and gave quicker results for the teacher in the short term. On the other hand, relational understanding involved meaningful learning and the pupil would be able to understand the links and relationships which gave mathematics its structure. It is clear that relational understanding is more beneficial in the long term and aids motivation. Skemp posited that both types of learning were deemed important for mathematics.

In Fennema et al.'s (1996) study, it was found that the teachers in the study were cognizant of the important criteria for making decisions about what and how to teach for student understanding. The teachers discovered that children should not be asked to practice procedures that the students did not understand. The teachers also knew that one way to find out if the student understood what was taught was to ask them to explain their thinking. Fennema et al. argued that oral and written communication could and should play a powerful role in instructional design and decisions. They also posited that through student communication about their mathematics thinking and ideas, teachers could better assess actual student understanding and design curriculum that best suited the students' needs. In sum, they concluded that by specifically targeting and meeting student needs, a deeper conceptual understanding would inevitably occur.

\section{Teams-Games-Tournaments(TGT)}

Teams-Games-Tournament (TGT), a generic teaching strategy developed by Edwards and De Vries (1972), is one of the learning approaches within cooperative learning used in any subject matter area. This method suggests the formation of student learning groups comprising of four to five heterogenous students in terms of ability, gender \& race. Each competing group will have representatives of students from the same level of ability (Slavin, 1986). Hence, in TGT, the groups compete with other groups which are of the same academic level with them. The focus of cooperative TGT learning is on the cooperation amongst members within each group and how the level of cooperation contributes towards the scores for the advancement of group value, while at the same time enhancing the individual value (Slavin, 1995; Joyce, Gall, Borg \& Walter, 1999; 
Mahony, 2006; Micheal, 2010). The primary instructional materials used in TGT are worksheets (Slavin, 1991). TGT has three basic elements, namely: (1) teams - students are randomly assigned into teams based on their having similar abilities and they remain in the same team throughout the cooperative learning process. (2) games - students involve in exercises designed by the teacher, and (3) tournament - students represent their teams and compete individually against students from other teams. The individual score contributes to the team's score (DeVries\&Slavin, 1976).

\section{METHODOLOGY}

The research design for this study was the Randomized PretestPostest Control Group Design involving two groups of students. The purpose of the study was to determine the effect of cooperative TGT on mathematics understanding and communication among the students at the Madrasah Aliyah (Aliyah Religious School) in Riau, Indonesia.The participants comprised randomly selected 64 Grade 11 students. The experimental group consisted of 32 students (20 males \& 12 females) and another 32 students in the control group (19 males \& 13 females). An open-ended mathematics test was used to measure the students' mathematics understanding (MU) and mathematics communication (MC).This test consisted of five structured items for mathematics understanding and five structured items for mathematics communication. All these items were adapted from the Indonesian National Mathematics Test. Cook and Campbell (1979) proposed that the same instrument could be used for the pretest and postest. Hence, in the study, the same instrument was administered twice, once during the pretest and the second time for the posttest. A mixed between-within subjects ANOVA (Tabachnick\&Fidell, 2007) was conducted to assess the effectiveness of cooperative TGT on mathematics understanding and communication of two different groups (control \& experimental groups with cooperative TGT) across three time periods [pre-test, post-test 1 and post-test 2 (without cooperative TGT)] as is shown in Figure 1.

The first group, called the experimental group had been given the pre-test prior to the use of cooperative TGT. The duration of intervention using cooperative TGT was five weeks, after which 
the students were given the post-test 1. After this stage, the use of cooperative TGT was withdrawn from the experimental group. This phase had also lasted for five weeks and at the end of this phase the students were given the post-test 2 (without cooperative TGT) (see Figure 1).

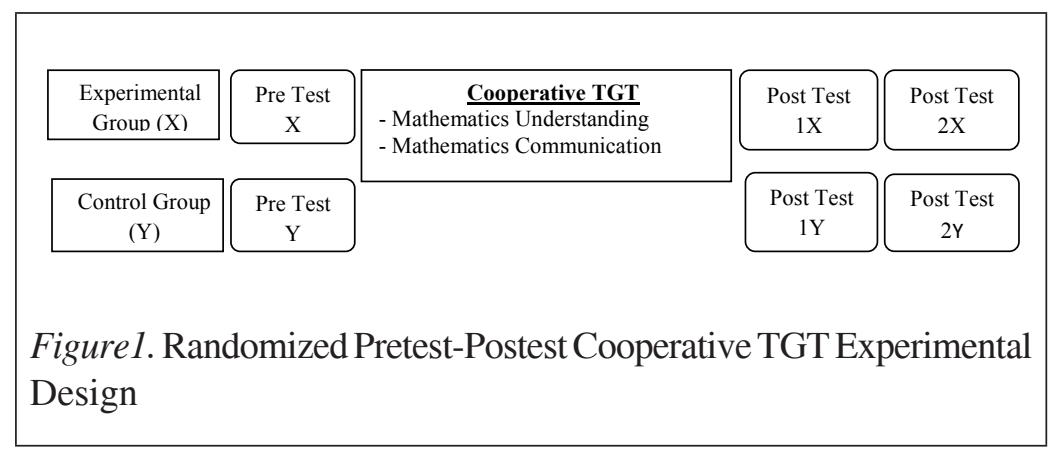

\section{Research Instruments}

As mentioned earlier, the main instrument used in the study was the test that comprised items which measured mathematics understanding (MU) as well as items that measured mathematics communication (MC). For MU items, students were required to write the concepts or formulas, followed by writing the procedural steps which involved applying or relating the formulas with other formulas and correctly arranging the solving strategies. For MC items, students were required to provide answers in the form of drawings, mathematical expressions and written texts (i.e., giving justifications based on logic). The scoring criteria for mathematics understanding and communication were based on the Holistic Scoring Rubrics developed by Cai, Lane, and Jakabcsin (1996). The maximum score for each MU and MC item was five (5) marks.

\section{RESULTS}

\section{Effect of Cooperative TGT on Student Mathematics Understanding}

There is a need to look into the interaction effect before determining the main effect in the test. Table 1 shows the results of the multivariate test which indicates the interaction effect between Factor $1 *$ group. 
The result of the interaction effect is significant (Wilks' Lambda $=$ $0.72, \mathrm{p}<.05)$. This shows that there is an interaction effect between cooperative TGT and the conventional approach towards the MU test. Interaction effect is a type of disordinal interaction because the teaching using cooperative TGT had increased MU and this relationship was positive (pre to post-1). Whereas using conventional teaching had shown a decline in MU and the relationship is negative (post-1 to post-2) (Hair, Anderson, Tatham, \& Black, 1998).

Table 1 shows Factor 1 MU in the pre-, post- 1 and post- 2 tests was significant (Wilks' Lambda $=0.12, \mathrm{p}<.05$ ). This result indicates that the cooperative TGT approach had increased student MU. Despite the existence of significant differences in mathematics understanding between the cooperative TGT and conventional groups, this result needs to obtain the effect size from partial eta squared. The result of the effect size, according to Cohen (1988) is big ( $\lambda=0.88)$.

Table 1

Multivariate Test for Cooperative TGT and Conventional Groups

\begin{tabular}{llcccccc}
\hline Effect & & Score & F & df & df error & p & $\lambda$ \\
\hline Factor 1 & Pillai's Trace & .88 & $226.73(\mathrm{a})$ & 2 & 61.00 & .00 & .88 \\
& Wilks' Lambda & .12 & & & & & \\
& Hotelling's Trace & 7.43 & & & & & \\
& Roy's Largest Root & 7.43 & & & & & \\
Factor $1 *$ & Pillai's Trace & .28 & $11.80(\mathrm{a})$ & 2 & 61.00 & .00 & .28 \\
Group & Wilks' Lambda & .72 & & & & & \\
& Hotelling's Trace & .39 & & & & & \\
& Roy's Largest Root & .39 & & & & & \\
\hline
\end{tabular}

The result of the between-subject effect test in Table 2 shows that the difference in mathematics understanding on the pre-, post-1 and post- 2 tests is significant $(\mathrm{p}<.05)$. This situation indicates the existence of main effect between mathematics understanding for the cooperative TGT and conventional groups. The group betweensubject effect shows a big effect size $(\lambda=0.15)$ which supports the significance of the study. From the mixed between-within subjects ANOVA, it is clear that the interaction effect between the cooperative TGT and conventional groups towards mathematics understanding 
is significant (Wilks' lambda $=0.72, \mathrm{~F}(2,61)=11.80, \mathrm{p}<.05, \lambda=$ 0.28 ), and the mathematics understanding main effect in the pre, post -1 and post- 2 is also significant (Wilks' lambda $=0.12, \mathrm{~F}(2,61)$ $=226.73, \mathrm{p}<.05, \lambda=0.88)$. The mathematics understanding main effect result on cooperative TGT and conventional is also significant $(\mathrm{F}(1,62)=11.24, \mathrm{p}<.05, \lambda=0.15)$.

Table 2

The Between-Subject Effect for the Cooperative TGT and Conventional Groups

\begin{tabular}{lcccccc}
\hline Source & Sum of Squares & df & Mean Square & F & p & $\lambda$ \\
\hline Constant $)$ & 19581.88 & 1 & 19581.88 & 2703.52 & .00 & .98 \\
Group & 81.38 & 1 & 81.38 & 11.24 & .00 & .15 \\
Error & 449.07 & 62 & 7.24 & & & \\
\hline
\end{tabular}

The effect of cooperative TGT learning in tests across three time periods, namely the pre-test, post-test 1 and post-test 2 (without cooperative TGT) is as shown in Table 3 below. Note that the mean score of mathematics understanding in the pre-test for the experimental group $(\mathrm{M}=6.16, \mathrm{SD}=2.22)$ and control group $(\mathrm{M}$ $=6.13, \mathrm{SD}=2.37$ ) showed equal variances based on Levene's test. A mixed between-within subjects ANOVA was also conducted to assess the effect of two different groups (control \& experimental with cooperative TGT) on students' scores on the mathematics understanding across three time periods (pre-test, post-test 1 and post-test 2 (without cooperative TGT)). There was significant interaction between group type and time periods, Wilks Lambda $=.72, \mathrm{~F}(2,61)=11.80, \mathrm{p}<.05$, partial eta squared $(\lambda)=0.28)$. The main effect for experimental group and control group was significant, $F(1,62)=11.24, p<.05$, partial eta squared $(\lambda)=0.15)$, suggesting a difference in the effectiveness of the cooperative TGT on mathematics understanding.

Figure 2 shows that the post 1 mathematics understanding score for the experimental group (14.53) is higher than the control group (11.09). This study has shown that there is a significant effect of cooperative TGT towards students' mathematics understanding. It can be seen that the difference in score (3.44) could be attributed 
to the significant effect of implementing cooperative TGT towards mathematics understanding. However, when the use of cooperative TGT was stopped after Post-test 1, the MU score (11.13) for the experimental group was equal to the score for the control group (conventional approach). This similar score could be the effect of withdrawing the cooperative TGT from the teaching.

Table 3

Mathematic Understanding Test for Pre-test, Post-test 1 and Posttest 2

\begin{tabular}{lcccccc}
\hline \multicolumn{1}{c}{ Mathematic } & \multicolumn{3}{c}{ Experimental group } & \multicolumn{3}{c}{ Control group } \\
\cline { 2 - 7 } \multicolumn{1}{c}{ Understanding Test } & $\mathrm{N}$ & Mean & $\mathrm{SD}$ & $\mathrm{N}$ & Mean & $\mathrm{SD}$ \\
\hline Pre-test & 32 & 6.16 & 2.22 & 32 & 6.13 & 2.37 \\
Post-test 1 & 32 & 14.53 & 2.03 & 32 & 11.09 & 1.91 \\
Post-test 2 (without & 32 & 11.13 & 2.14 & 32 & 11.13 & 2.47 \\
cooperative TGT) & & & & & & \\
\hline
\end{tabular}

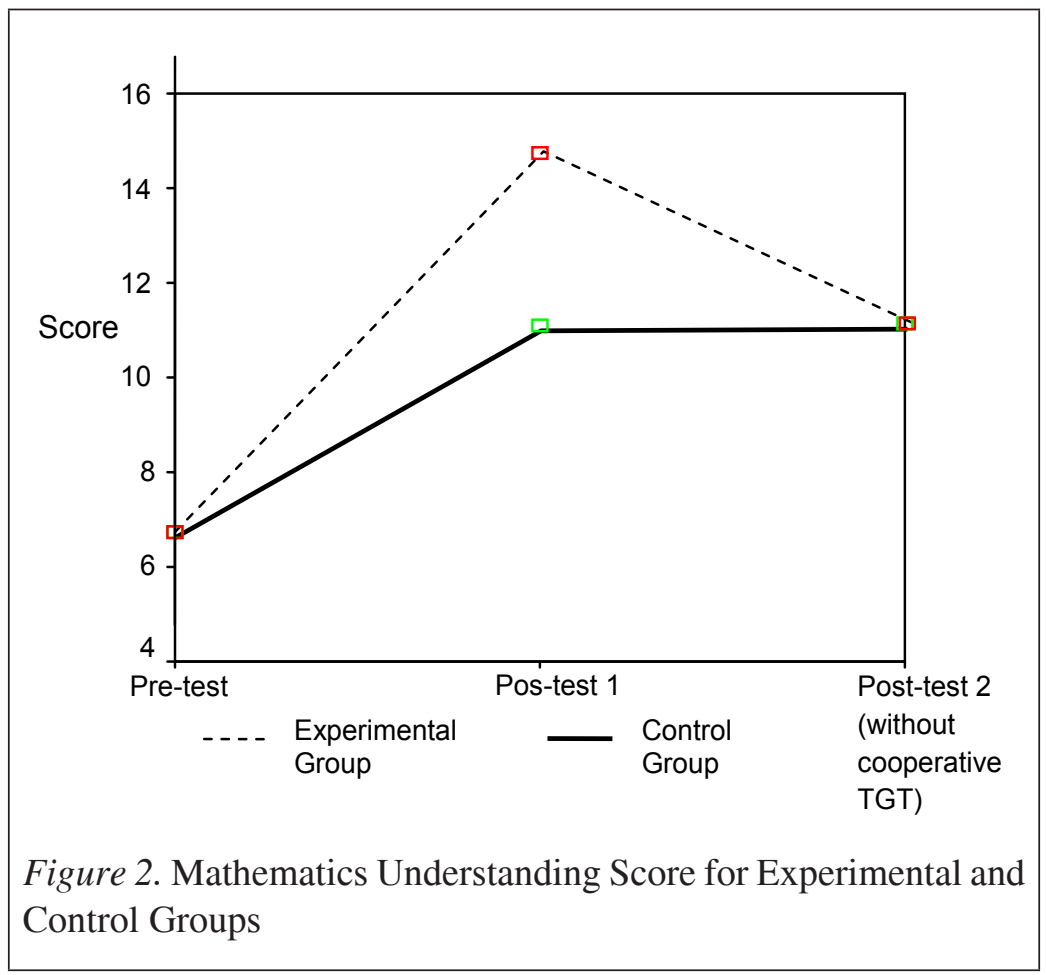




\section{EffectofCooperative TGT on Student Mathematics Communication}

The multivariate test, as shown in Table 4, is an indicator to determine the interaction effect. The result of the multivariate test shows the interaction effect between Factor $1 *$ group. The interaction effect finding is significant (Wilks' Lambda $=0.89, \mathrm{p}<.05$ ). This indicates that interaction effect existed between cooperative TGT and conventional groups for the MU test.The type of interaction effect was disordinal interaction because the teaching interaction with cooperative TGT was found to enhance MU and the relationship was positive (pre- to post-1). On the other hand, with conventional teaching, there was a decrease in MU and the relationship was negative (post-1 to post-2) (Hair, Anderson, Tatham, \& Black, 1998).

Based on Table 4, it can be seen that Factor 1 mathematics communication in the pre-, post-1 ad post-2 tests is significant (Wilks' Lambda $=0.08, \mathrm{p}<.05$ ). This result indicates that cooperative TGT method had an effect on the increase of student mathematics communication. The result of the analysis showed that there exists a significant difference for mathematics communication between cooperative TGT and conventional groups. This result needs to obtain effect size from partial eta squared. The effect size result, according to Cohen (1988), is big $(\lambda=0.92)$.

Table 4

Multivariate Test for Cooperative TGT and Conventional Groups

\begin{tabular}{llcccccc}
\hline Effect & & Score & F & df & df error & $\mathrm{p}$ & $\lambda$ \\
\hline Factor 1 & Pillai's Trace & .92 & $332.04(\mathrm{a})$ & 2 & 61.00 & .00 & .92 \\
& Wilks' Lambda & .08 & & & & & \\
& Hotelling's Trace & 10.89 & & & & & \\
& Roy's Largest Root & 10.89 & & & & & \\
Factor 1* & Pillai's Trace & .11 & $3.87(\mathrm{a})$ & 2 & 61.00 & .03 & .11 \\
Group & Wilks' Lambda & .89 & & & & & \\
& Hotelling's Trace & .13 & & & & & \\
& Roy's Largest Root & .13 & & & & & \\
\hline
\end{tabular}




\section{Between-Subject Effect}

Table 5 shows that the between-subject test effect difference on mathematics communication in pre-, post- 1 and post- 2 test, is significant. This result shows that there exists main effect difference in mathematics communication between cooperative TGT and conventional groups. The findings of the group between-subject effect shows that the effect size $(\lambda=0.07)$ moderately supports the overall study findings.

Table 5

Between-Subject Effect for Cooperative TGT and Conventional Groups.

\begin{tabular}{lcccccc}
\hline Source & Sum of Squares & df & Mean Square & F & p & $\lambda$ \\
\hline (Constant) & 92444.63 & 1 & 92444.63 & 2666.48 & .00 & .98 \\
Group & 166.88 & 1 & 166.88 & 4.81 & .03 & .07 \\
Error & 2149.49 & 62 & 34.67 & & & \\
\hline
\end{tabular}

Table 6 shows that the score of mathematics communication in the pre-test of the experimental $(\mathrm{M}=11.56, \mathrm{SD}=2.92)$ and control group $(\mathrm{M}=11.31, \mathrm{SD}=2.83)$ has assumed equal variances based on Levene's test. A mixed between-within subjects ANOVA was conducted to assess the effect cooperative TGT on student mathematics communication scores across three time periods (pretest, post-test 1 , and post-test 2 (without cooperative TGT)). There was significant interaction between group type and time periods, (Wilks Lambda $=0.89, \mathrm{~F}(2,61)=3.87, \mathrm{p}<.05$, partial eta squared $(\lambda)=0.11)$. The main effect for experimental group and control group was significant, $\mathrm{F}(1,62)=4.81, \mathrm{p}<.05$, partial eta squared $(\lambda)=$ $0.07)$, suggesting a difference in the effectiveness of the cooperative TGT teaching approaches on mathematics communication.

Figure 3 shows that the post 1 mathematics communication score for the experimental group (32.22) is higher than the control group (26.69). This study has shown that there is a significant effect of cooperative TGT towards student mathematics communication. It 
can be seen that the difference in score (5.53) could be attributed to the significant effect of implementing cooperative TGT towards mathematics communication. However, when the use of cooperative TGT was stopped after Post-test 1, the mathematics communication scores (25.03) for the experimental group is almost equal to the score for the control group (conventional approach) (25.00). This almost similar score could be the effect of withdrawing the cooperative TGT from the teaching.

Table 6

Mathematic Communication Test for Control and Experimental group

\begin{tabular}{lcccccc}
\hline \multirow{2}{*}{$\begin{array}{c}\text { Mathematic } \\
\text { Communication Test }\end{array}$} & \multicolumn{3}{c}{ Experimental group } & \multicolumn{3}{c}{ Control group } \\
\cline { 2 - 7 } & N & Mean & SD & N & Mean & SD \\
\hline Pre-test & 32 & 11.56 & 2.92 & 32 & 11.31 & 2.83 \\
Post-test 1 & 32 & 32.22 & 6.47 & 32 & 26.69 & 9.16 \\
Post-test 2 (without cooperative TGT) & 32 & 25.03 & 4.06 & 32 & 25.00 & 3.97 \\
\hline
\end{tabular}

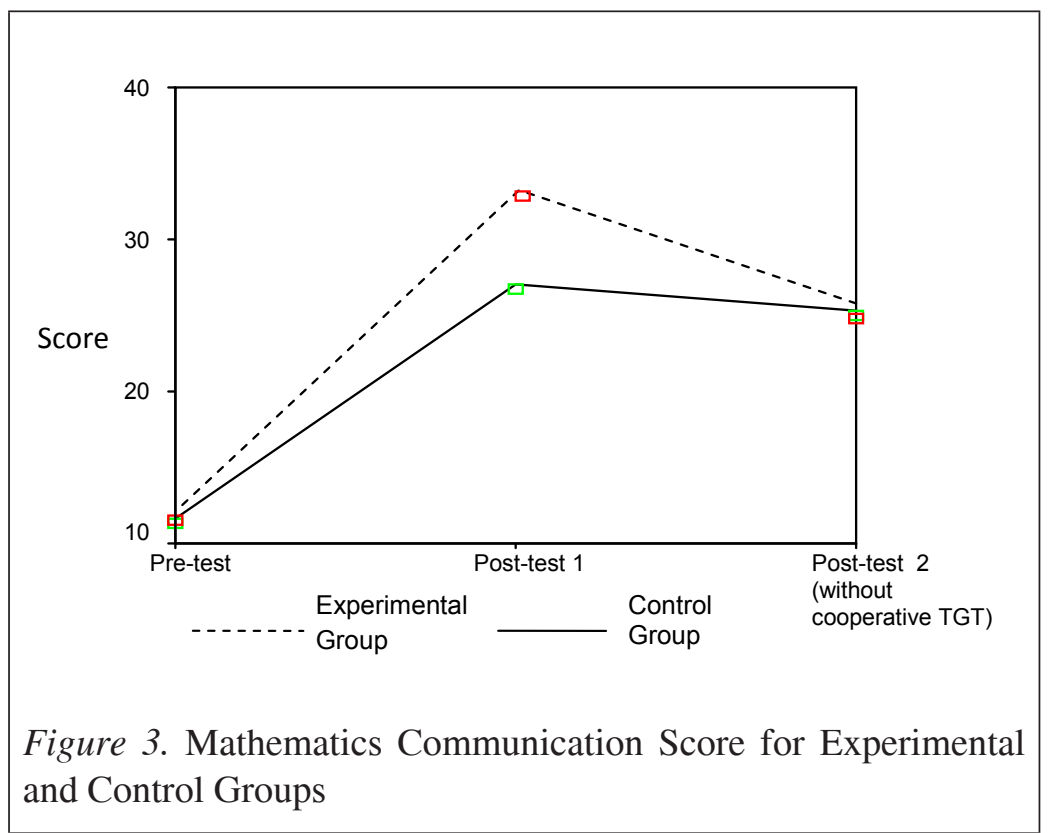




\section{DISCUSSION}

\section{Effect of Cooperative Learning on Student Mathematics Understanding}

This study found that there was an effect of cooperative TGT learning on mathematics achievement, which can be seen from the higher mean score in mathematics understanding using cooperative TGT learning compared to convensional learning. This finding is parallel to the one in Graceful and Raheem (2011) that investigated the effect of Think-Pair-Share (TPS) cooperative learning and Reciprocal Teaching (RT) on student performance in mathematics understanding. Their research showed that RT cooperative learning approach was the most effective approach for mathematics understanding, followed by the TPS cooperative learning approach, and the lowest was when using the conventional approach. This present study also indicated similar results from the use of cooperative learning, whereby students could come face-to-face with each other and discuss, exchange information, help friends, share different views, receive instant feedback and encourage each other. During the interaction with peers, students were able to explain the ideas and methods in mathematics in their own words, and helped each other in the process of mathematics understanding. This finding corroborates the findings in the study by Charalampos (2004) which showed that student involvement in the cooperative group activitities had contributed towards an increase in student understanding of mathematical concepts. Students were also motivated and begun to change their attitude, improve attendance and appreciate the importance of concepts in mathematics. They became engaged in the solution of mathematical tasks and showed readiness to participate in tasks.

The current study's findings also supported the studies by Tunner and Marr (1997), Slavin (1997) and Whicker (1997) which asserted that cooperative learning methods would enable students to receive positive feedback through the processes of inculcating thinking skills, problem solving and group interaction. This study has shown that shared tasks had resulted in better understanding of mathematics concepts and acquisition of mathematics skills. Students had 
learned to sort and orient ideas towards complex mathematical tasks and had been able to provide logical explanations. When students interact with their peers during the process of cooperative learning, conflicting opinions may arise due to the different levels of competence in conceptual understanding of mathematics among them. As expounded by Piaget's theory, conflicting opinions would bring about an imbalance in student cognitive processes. Consequently, students will work to balance the cognitive processes by understanding the concepts from a new perspective based on the discussions with their more competent peers.

The results in the current study also supported Linda's (2004) finding that Form Four students from the district of Sibu, Sarawak, who had followed the Jigsaw cooperative learning method exhibited a higher level of understanding of science concepts compared to those in the control group who were exposed to the traditional learning method. However, the findings in the current study seem to contradict the results in Ansari (2005) who reported that the inculcation of Thinf-Talk-Write (TTW) cooperative learning method was not yet effective because the understanding capability mean score had not reached the threshold score. According to Ansari, such a result could be attributed to other factors: the lack of prerequisite knowledge among students, the learning process that all this while was teacherfocused, and the lack of student reading and discussion competence, as well as the high classroom enrolment.

\section{Effect of Cooperative Learning on Student Mathematics Communication}

This study showed that cooperative TGT learning had an effect on mathematics communication. This is clearly seen in the mathematics communication mean score of students who experienced the cooperative TGT learning approach. The student scores in the experimental group were higher compared to that of those in the conventional learning group. Similar results were found in the study carried out by Tsay and Brady (2010), which reported that there existed a positive relationship between academic performance and communication ability for those students who participated in cooperative learning. The result of the current study supported 
the idea that cooperative learning is an active pedagogy for the achievement of higher academic performance. Additionally, the result of the study also indicated that group values and achievements are more important to students compared to peer acceptance and the feeling of success, despite the literature indicating the strong relation and dependence on group success (Johnson\& Johnson, 1991).

Further corroboration of the results of the present study is found in the study by Amy and Omaha (2011), which had looked at the effect of the cooperative group on written and oral mathematics communication among a sample of Grade 8 American students. Their study showed that there was an increase in mathematics written and oral communication through interactions between students and their peers and the students had worked more comfortably in groups. Similarly in Keri and Plattsmouth's (2010) study, which was also on cooperative learning, it was found that there was an increase in mathematics communication, especially in vocabulary use and verbal discussions. The approach also supported students in acquiring mathematics concepts. The findings are corroborated in Galton, Hargreaves and Pell (2009) who found that cooperative learning was effective in increasing student communication because when the students were in the group, they worked together, discussed and performed the tasks given to them freely and without feeling fear towards other students. These findings also supported the result of Shield's (1996) study which had highlighted that in student discussions, there was the need to have verbal communication skills and these would be enhanced by well organized training.

In Indonesia, the study by Ulya (2007) had also supported the effectiveness of cooperative TGT learning. Ulya had reported that student mathematics communication had increased for those who were in the cooperative TGT group compared to those in the conventional group. The current study also found that students in the cooperative TGT learning group were more active and constantly discussing; and during academic competitions, they were constantly competing to obtain better scores. Mathematics teachers need to diversify the teaching and learning methods used in their mathematics classrooms. The approach used should not be limited to only the delivery of lesson content via the lecture approach only 
and giving the reason of wanting to finish the syllabus without considering the students' level of understanding. Teachers should not only focus on individual drills and practices. Teachers should use the cooperative TGT learning approach in ther teaching and learning proceses because this method had been tested numerous numbers of times and it was found that this cooperative approach had helped to increase student understanding and their mathematics communication. According to Melvin and Silberman (2006), in cooperative TGT learning processes, the learning groups would have to engage in group competitions and this would be useful in ehnacing multi facts learning, the understanding of mathematical concepts, as well as enhancing mathematics communication.

\section{Implication and the Way Forward}

This study has provided empirical evidence that cooperative TGT instruction can be an alternative innovative teaching approach to develop positive attitudes in learning mathematics. The schools and/ or the mathematics teachers can consider findings presented here as the basis for using cooperative TGT learning in mathematics classrooms or as an alternative teaching method for the learning of mathematics. The findings had found that the students' attitude towards learning mathematics had increased and they exhibited greater interest and motivation in learning mathematics. Hence, mathematics teachers should consider their students' preferences of their respective learning style or approach and then design appropriate group work activities during the process of teaching and learning mathematics.

Educators could design effective cooperative TGT instructions, which provide hands-on experience in mathematical concepts and computations. Cooperative TGT will be able to facilitate student learning, especially in solving more complex mathematical problems which are challenging. Interactive and cooperative learning have helped overcome learning barriers in mathematics. In sum, it is important for educators to adopt cooperative learning as an appropriate approach to continuously enhance the learning of mathematics in classrooms. The Ministry of Education and Education Departments, especially the Teacher Services Division, need to 
provide inhouse training or short courses to current mathematics teachers to assist them in using cooperative TGT learning in their classrooms. Incentives ought to be given as appreciation for mathematics teachers who have initiated the use of new teaching approaches. This would encourage teachers to have an innovative attitude, as well as become creative in enhancing their teaching and learning ativities in classrooms. Since the concept of cooperative TGT learning is in line with the Aliyah Religious School curriculum, the Indonesia Education Ministry needs to establish a guideline, whether in the form of modules or manuals, for all the mathematics teachers. This is because the concept of cooperative TGT learning is different from the unstructured conventional group work.

The study has highlighted the process of learning and teaching mathematics within the context of a religious school in Southeast Asia. It is worth noting that Indonesia is a country which has numerous religious schools. Students at these schools need to learn both academic and religious subjects, a situation transcending the majority of religious schools in Southeast Asia. The teaching of mathematics has almost always been traditional in nature, whereby students are passive learners. For instance, student-centred learning is not dominant in religious schools in Riau, Indonesia. The finding in this study has shown that student engagement in the process of learning mathematics was enhanced when the cooperative TGT approach was employed in the mathematics classroom. To learn mathematics actively, there is a need to incorporate the three major components of the cooperative TGT learning approach, namely 'team', 'games' and 'tournament'.

Through the cooperative TGT learning approach, students at this religious school had been given the opportunity to experience relational understanding. According to Skemp (1986), the meaningful learning of mathematics would enable students to better understand the links and relationships between mathematical concepts and their structure. The findings in this study should raise awareness among mathematics teachers in religious schools with regards to the importance of giving attention to the notion of mathematics understanding and communication in the mathematics classrooms. Students need to be given opportunities to talk about the process of solving mathematical problems. Cooperative TGT had created 
a conducive learning environment by allowing peer collaboration within student groups, while members would concurrently compete as they strive to enhance their understanding of mathematics. The findings in this study would be a signal for the Indonesia Ministry of Education to endorse cooperative TGT as one of the effective mathematics teaching approaches for religious schools. Moreover, cooperative TGT has the potential to enhance moral and social values among students at these religious schools.

\section{CONCLUSION}

Since the sample is limited to Grade 11 students in one religious school in Riau, Indonesia, and with an intervention lasting only 10 weeks, any generalization drawn from this study should be considered with caution. Changing the way students work together can make a real difference in improving mathematics understanding and communication among the students in the religious school in this study. Using cooperative TGT has enhanced student interest to actively learn mathematics with their peers via tournaments. In the conventional approach, students were found to be more individualistic and reserved. Students in the cooperative TGT classrooms, however, had learned to socialise while learning mathematics. They no longer only concentrated on their own learning but instead shared their mathematics understanding with their team members as well as their other classroom peers. Hence, students in cooperative TGT classrooms, have become more active learners compared to their peers exposed only to the conventional learning approach. Cooperative TGT also helps the teachers to maximize student engagement in the mathematics classroom. Additionally, this study has also found that cooperative TGT could produce positive effects on mathematics understanding and communication, and has fundamentally changed what the Madrasah Aliyah students do every day in their core mathematics classes.

\section{REFERENCES}

Amy, S. G., \& Omaha, N. E. (2011). Cooperative groups in eighth grade math. Project Report. University of Nebraska-Lincoln. 
Ansari, B.I. (2004). Menumbuhkembangkan kemampuan pemahaman dan komunikasi matematis siswa SMU

Melalui strategi think-talk-write. Disertasi Doktor pada PPS UPI Bandung: Tidak Diterbitkan.

Cai, J., Lane, S., \& Jakabcsin, M. S. (1996). In P.C Elliot., \& M.J Kenney (Eds.). The role of open-ended tasks and holistic scoring rubrics: Assessing student's mathematical reasoning and communication, yearbook communication in mathematics K-12 and beyond. Reston, VA: The National Council of Teachers of Mathematics.

Charalampos, T. (2004). Cooperative study teams in mathematics classrooms. International Journal of Mathematical Education in Science and Technology, 35(5), 669-679. DOI: 10.1080/0020739042000232529.

Chung S. C., \& Cheng C. T. (2005) Exploration on Integrating Information Technology into Mathematics Instruction. Journal of Educational Media \& Library Sciences, 43(2), 249-266.

Cook, T. M., \& Camphell, D. T. (1979).Quasi-experimentation: Design \& analysis issues for field settings. Boston Mass: HougtonMiffin.

Fennema, E., Carpenter, T., Franke, M., Levi, L., Jacobs, V., \& Empson, S. (1996). A longitudinal study of learning to use children's thinking in mathematics instruction. Journal for Research in Mathematics Education, 27, 403-434.

Galton, M., Hargreaves, L., \& Pell, T. (2009). Group work and whole-class teaching with 11- to 14 year olds compared. Cambridge Journal of Education, 119-140.http://dx.doi. org/10.1080/03057640802701994

Graceful, O., \& Raheem, A. L. (2011). Cooperative instructional strategies and performance levels of students in reading comprehension. International Journal of Educational Science, 3(2), 103-107.

Huinker, D., \& Laughlin, C. (1996). Talk you way into writing. In. P. C. Elliot, \& M. J. Kenney (Eds). Years Book 1996. Communication in mathematics $K-12$ and beyond. USA: NCTM

Isrok', A. (2006). Pembelajaran matematik dengan strategi koperatif tipe teams achievement divisions Untuk meningkatkan kemampuan pemecahan masalah dan komunikasisiswa SMA (Tesis Sarjana yang tidak diterbitkan).Universitas Pendidikan Indonesia, Bandung. 
Johnson, D. W., \& Johnson, R. T. (1991). What to say to people concerned with the education of high ability and gifted students. Unpublished manuscript.

Joyce, P., Gall, M.D, Borg., \& Walter, R. (1999). Cooperative learning. Applying educational research: A practical guide (4th ed.), 144-118. New York: Longman.

Kamuran T. \&Fikri A. (2008) The effects of cooperative learning on Turkish elementary students' mathematics achievement and attitude towards mathematics using TAI and STAD methods. Educ Stud Math, 67, 77-91.

Ke, F., \& Grabowski, B. (2007). Gameplaying for math learning: cooperative or not? British Journal of Educational Technology, 38(2), 249-259.

Keri, W., \& Plattsmouth, N. E. (2010). Communication of mathematics within cooperative learning Groups. In partial fulfillment of the MAT Degree Department of Mathematics University of Nebraska-Lincoln.

Linda, T. M. (2004). Satu kajian keberkesanan Pembelajaran Koperatif (kaedah Jigsaw) dalam mata Pelajaran sains tingkatan empat di daerah Sibu, Sarawak. (Skripsi Sarjana Muda). UniversitiTeknologi Malaysia.

Melvin., \& Silberman. (2006). Active learning. Penerbit Nusa Media. Bandung.

Micheal, M.V. (2010). The effects of teams-games-tournaments on achievement, retention and attitudes of economics education students. Conference Proceedings, University of the Free State, South Africa.

Mullis, I. V. S., Martin, M. O., Foy, P., \& Arora, A. (2012). TIMSS 2011 International results in mathematics. Chesnut Hill, MA: TIMSS \& PIRLS International Study Center, Lynch School of Education, Boston College \& Amsterdam.

National Research Council. (1999). How people learn: Brain, mind, experience, and school. In J. D. Bransford, A. L. Brown, \& R. R. Cocking (Eds.), Committee on developments in the science of learning, commission on behavioral and social sciences and education. Washington, DC: National Academy Press.

Rosna Awang-Hashim, Arsaythamby Veloo, \& Ruzlan Md. Ali. (2014). Mathematics achievement of eight grade students in ASEAN countries based on selected characteristics. In TIMSS 2011: What Can We Learn Together? SEAMEO-RECSAM Penang. 
Skemp, R. R. (1986) The psychology of learning mathematics (2nd ed.). London: Penguin Books.

Slavin, R. E. (1990). Cooperative learning: Theory, research and practice. Massachussetts: Simon \& Schuster Inc.

Slavin, R. E. (1995). Cooperative learning theory, research, and practice (Second Edition). America: Allyn and Bacon.

Slavin, R.E. (1997). When does cooperative learning increase students achievement? In Dubinsky and D. Mathews (Eds), Reading in cooperative learning for undergraduate mathematics.

Washington DC: The Mathematical Associaton of America.

Supriyono. (2011). Developing mathematical learning device using TTW (Think- Talk-Write) strategy assisted by learning CD to foster mathematical communication. Paper presented at International Seminar and the Fourth National Conference on Mathematics Education, Yogyakarta.

Tabachnick, B. G., \& Fidell, L. S. (2007). Using multivariate statistics (5th ed.). Boston: Pearson Education.

Tanner, K., \& Marr, M. B. (1997). Cooperative learning: Brief review, reading and writing quarterly: Overcoming, Learning Difficulties, 13, 7-20.

The National Council of Teachers of Mathematics (2006). Principles and standards for school mathematics. Reston, VA: NCTM.

Tsay.M., \& Brady,M. (2010). A case study of cooperative and communication pedagogy. Journal of the Scholarship of Teaching and Learning, 10, $78-89$.

Ulya,N. (2007). Upaya meningkatkan kemampuan penalaran dan komunikasi matematik siswa SMP/MTS melalui pembelajaran kooperatif Tipe Teams-Games-Tournaments (TGT). (Tesis PPS UPI) Bandung: Tidak diterbitkan.

van Es Elizabeth, A., \& Conroy, J. (2009). Using the performance assessment for California teacher to axamine pre-service teachers' conceptions of teaching mathematics for understanding. Issues in Teacher Education. University of California, Irvine.

Whicker, K. M., Bol. L., \& Nunnery J. A. (1997). Cooperative in the secondary matematics classroom. The Journal of Educational Research, 91, 42-48.

Wiebe-Berry, R. A., \& Kim, N. (2008). Exploring teacher talk during mathematics instruction in an inclusion classroom. Journal of Educational Research, 101(6), 363-378. 
Wihatma, U. (2004). Meningkatkan kemampuan komunikasi matematik siswa SLTP melalui "Cooperative Learning” tipe student Teams-Achievement Divisions (STAD) (Tesis sarjana yang tidak diterbitkan). Universitas Pendidikan Indonesia, Bandung. 